\title{
ON STEPHEN E. FIENBERG AS A DISCUSSANT AND A FRIEND
}

\author{
By DONALD B. RUBiN \\ Harvard University (emeritus), Tsinghua University and Temple University
}

I first met Steve when I was changing PhD programs at Harvard in 1967 or 1968. After entering the PhD program in Psychology for a week, I had been in "The Division of Engineering and Applied Physics" in a program that would now be called computer science, doing things like learning about automata theory, extensible languages, Chomsky grammars, Turing Machines, computational complexity and writing computer programs in assembly code for a PDP-1, which used folded paper tape for storing the code. Riveting stuff I had grown to unlove. I believe that in 1967 I had spoken to Fred Mosteller, at the advice of John Tukey (whom I knew pretty well from my undergraduate days because I had done some programming for him at Bell Labs). The reason for this digression about my background is to emphasize that I knew essentially nothing about statistics as a field, really not even what it was at that point in time, and Steve in contrast appeared to be immersed in it, having worked with Fred for years and knew the other two senior faculty in Statistics on a first name basis (Art Dempster and Bill Cochran). Although Steve had already completed the lower level PhD courses, we both attended a seminar lead by Fred where we discussed psychological learning theory (Bush and Mosteller), log-linear models (Leo Goodman style) and other truly interesting things to which I'd never been exposed. Statistics was a great fit for me, and it occurred to me at the time that Steve was clearly going to be a leader in this field.

As is well-known, Steve went on to become a member of the Statistics Department Faculty at the University of Chicago. I stayed at Harvard for a year after I graduated, but Steve and I connected again when we were both asked to be discussants of a paper on missing data by HO Hartley and Ron Hocking at a Biometrics Society meeting.

For those who have never met Hartley, he was a real character. He was fairly short, possibly under five feet, with a heavy German accent, which he exaggerated by speaking in an overly precise, staccato style. Hartley presented the paper. Then after one or two other discussants, Steve presented his discussion with his usual eloquence, which I had learned to expect and respect from our time together at Harvard; Steve was already a "player" in Statistics. Then it was Hartley's turn to comment on Steve's points. He began: "I want to begin by thanking Professor FEEN-BERGG for his discussion.” It seemed to me that it took Hartley about a

Received December 2017. 
minute to pronounce Steve's last name, in the correct German pronunciation of the name, with about 30 seconds on the "EEN". Steve sat politely listening; HO was not shy about keeping the stage, but after a while Steve got his chance for a rejoinder to HO's comments. He started by very politely correcting $\mathrm{HO}$ by saying something like, "Here in North America, we pronounce my last name as FINEberg." But HO wasn't yet done. After a while he rose, this time sort of rocking back and forth on his toes, apparently in an attempt to achieve a bit of extra height (to match Steve's?), and began: "I want to thank Professor FEEN-BERG..." and the audience broke up! I remember essentially nothing else about the session, including the technical content, but it was absolutely hilarious and simultaneously personally educational! Educational because Steve remained calm and polite despite HO's apparent provocation, and it was clear to me that this sort of response was far more effective than a juvenile defensive one. I learned to like $\mathrm{HO}$ a lot and his style and his sense of humor - a very warm guy who was passionate about statistics, but he could enjoy provocation, as this event illustrated.

I have since wondered why HO was so insistent on the text-book German pronunciation of Steve's last name, especially because, as I learned later, his name was not really Hartley, but rather Hirschfeld, actually Herman Otto Hirschfeld. HO was a very talented statistician who won an early Wilks Medal of the ASA, and at one time was the ASA president. Maybe HO thought that if you have a name with nice German pronunciation, you should use it, but if so, why change his own?

This anecdote illustrates Stave's equipoise under pressure, an admirable quality of his, which contributed to his great success on the world stage of statistics, especially considering the variety of important committees that he has chaired and to which he has testified. I, in contrast, have no such gift.

I know this little snippet of a story about Steve has essentially zero statistical content, but it may reveal to some why Steve had some special personal qualities that were important gifts that contributed to make him an especially effective statistical representative for many of his colleagues.

Department of Statistical SCIEnCE FoX SCHOOL OF BUSINESS TEMPLE UNIVERSITY

Philadelphia, Pennsylvania 19122 USA

E-MAIL: dbrubin@mac.com 